\title{
The Jazz-Flamenco Connection: Chick Corea and Paco de Lucía Between 1976 and 1982
}

\author{
Juan Zagalaz
}

\section{INTRODUCTION}

Leonard Feather's famous quote, "Spain, a desert for jazz," is usually cited as an example of the state of jazz within the Iberian borders. Nevertheless, Spain, under Arabic influence from 711 until 1492, has produced several high-quality and remarkably original recordings over the decades, reflecting certain characteristic and specific cultural traits at different artistic levels. The most international representation is flamenco, recently recognized by UNESCO as an "Intangible Cultural Heritage." Flamenco, consolidated in the nineteenth century after a long process, contains essences of HispanicArabic culture, as well as elements from Roma settlements and the inhabitants of the peninsula. It is, therefore, a complex art that incorporates interesting melodic, harmonic and, above all, rhythmic features.

Musicians from a wide variety of backgrounds have shown interest in Spanish music and particularly in flamenco. Within the jazz world, musicians such as Lionel Hampton, Miles Davis and John Coltrane have approached flamenco with different degrees of depth in their works, although the one who took the most significant steps forward was Chick Corea, whose collaboration with flamenco guitarist Paco de Lucía, resulted in several recordings and a process of mutual acculturation. This acculturation, in turn, spread to a group of musicians who developed the skills to function in both environments and whose subsequent individual creations are generally recognized as Jazz-Flamenco. These musicians, Spaniards Jorge Pardo and Carles Benavent, along with Brazilian Rubem Dantas, joined the famous Paco de Lucía Sextet and, later, Chick Corea's band, in addition to collaborations with other musicians such as Pat Metheny and Miles Davis. ${ }^{1}$

This article reviews both the beginning of the musical relationship between two leading representatives of each style, Chick Corea and Paco de Lucía, as well as their individual recordings, from the release of Corea's popular My Spanish Heart, in 1976, through de Lucía's Paco de Lucia Interpreta a Manuel de Falla (1978) and Solo Quiero Caminar (1981), and on

\footnotetext{
${ }^{1}$ Pardo and Benavent were invited along with other musicians, to play with Pat Metheny on July $18^{\text {th }}, 2003$, at the Festival De Jazz de Vitoria, Spain. In 1991, Benavent was invited to perform at a special tribute to Gil Evans at the Montreux Festival with Miles Davis and Quincy Jones.
}

copyright by author $9 \bigoplus \bigoplus \bigoplus \begin{aligned} & \text { Except where otherwise noted, this work is licensed under } \\ & \text { http://creativecommons.org/licenses/by-nc-nd/3.0 }\end{aligned}$ 
to the guitarist's collaboration with Corea on the pianist's Touchstone (1982). It also seeks to review the work of the various emerging Spanish musicians in order to identify, insofar as possible, the aesthetic origins of what would later be named Jazz-Flamenco.

\section{FLAMENCO: AN OVERVIEW}

The flamenco art is studied in depth by contemporary scholars, but its historiographic roots harken back to the second half of the 19th century when Antonio Machado y Álvarez ${ }^{2}$ used his pseudonym "Demófilo" to publish several writings about Andalusian folklore. One area of debate among flamenco scholars is the degree of participation of the Roma, even though the Andalusian and Roma interaction is generally accepted. ${ }^{3}$

According to the most recent research, we can define flamenco as an art established during the 19th century but shaped by the complex interaction between a series of diverse elements. The Tartessians ${ }^{4}$ merged their native songs with Phrygian and Ionian sonorities from Byzantine liturgical chants. ${ }^{5}$ According to Sabas de Hoces, cited in the work of Manuel Ríos Ruiz, Visigoth chant and pre-Islamic poetry coexisted between 500 and $700 \mathrm{AD}$, a period that was followed by the emergence of early flamenco poetry, catalogued as protoflamenco. ${ }^{6}$ Between 822 and 852, the musician and educator Ziryab, ${ }^{7}$ who came from Baghdad to work for the Umayyad emir of Córdoba, Abd ar-Rahman II, introduced Indian elements. $^{8}$

\footnotetext{
${ }^{2}$ Antonio Machado y Álvarez was the father of Antonio and Manuel Machado, two of the most important Spanish poets and leading figures of the Generation of '98.

${ }^{3}$ According to flamencologist Miguel Ángel Berlanga (2008, 17-38), regarding the participation of the gypsy community in shaping flamenco, this would be a "specific gypsy reinterpretation [...] of a musical heritage that is Andalusian in its essence." Similarly, Mairena and Molina (1979) believe that, while the Gypsies didn't bring flamenco, nor are they the sole people responsible for developing the art form; they "forged it with metals that were mostly Andalusian.” This explains the fact that only the Andalusian gypsies, and not those from other regions of Spain or Europe, developed this type of art. Álvarez Caballero (1988) also supports this thesis, as he states that "the Gypsies didn't learn the singing of the Andalusians, rather they created it in Andalusia, assimilating indigenous materials."

${ }^{4}$ Tartessos was the name of a pre-Roman civilization around the Guadalquivir River, southern Spain.

${ }^{5}$ Manuel Ríos Ruiz, Introducción al Cante Flamenco (Madrid: Ediciones Itsmo, 1972), 26.

${ }^{6}$ Manuel Ríos Ruiz, El Gran Libro del Flamenco. Vol. I (Madrid: Calambur Editorial, 2002), 26.

${ }^{7}$ According to Lévi-Provenzal, Ziryab (Black Bird) created a conservatory in Córdoba where the Andalusian music, initially very similar to the oriental school of Master Ishaq alMawsilí, acquired a completely original dimension. Évariste Lévi-Provenzal, La Civilización Árabe en España (Madrid: Espasa Calpe, 1955), 69.

${ }^{8}$ Ríos Ruiz (1972), 26.
} 
Subsequently, autochthonous Mozarabic ${ }^{9}$ compositions were established, including the moaxaja, the jarcha and the zéjel. ${ }^{10}$ According to specialist Álvarez Caballero, in 1425 the Gypsy community arrived in the Iberian Peninsula through the Pyrenees, crossing the Kingdom of Aragón. ${ }^{11}$ They were initially well received, as they bore noble titles, carried papal letters (albeit of dubious authenticity), and told fabulous stories about their origins and status. It was just a matter of time before their customs clashed with those of Spain's inhabitants, setting off a sequence of events that resulted in the repression of the Gypsy people. Thus, a new era began with "La Pragmática," issued by the Catholic Kings in 1499, in which the rules and limitations for the Gypsies were much more severe than for the rest of the citizens, influencing their way of understanding and expressing their art. ${ }^{12}$ After more than two centuries of constant repression, the situation seemed to ease, at least outwardly, starting with "La Pragmática," issued by Carlos III in 1783. Actually, starting in the nineteenth century, the increased integration of the Gypsies into certain areas of southern Spain ${ }^{13}$ culminated in the process of acculturation. The creation of flamenco as a style, however, resulted from its professionalization in the second half of 19th century, ${ }^{14}$ thanks to the emergence of the "Cafes Cantante," places where flamenco developed and which created a competitive atmosphere among artists. These establishments were similar to clubs in the United States which featured jam sessions during the 1930s and 1940s. Musically, flamenco performances contained a series of specific characteristics that distanced it from other popular Andalusian and Spanish musical genres. The different typologies of cante ${ }^{15}$ are called palos. Palos are musical structures with specific rhythmic, melodic, and harmonic characteristics, with a remarkable use of accent distribution and a complex time signature. One of the most popular palos is the buleria, built over a 6/8 - 3/4 alternation, emphasizing the strong beats of both bars:

\footnotetext{
${ }^{9}$ Mozarab: relating to the Christian inhabitants of Spain under the Muslim Moorish kings. In online Oxford dictionaries:

http://oxforddictionaries.com/definition/Mozarabic\#m_en_gb0538500.003. [Last consult: 2011-10-06]

${ }^{10}$ Ríos Ruiz (2002), 28.

${ }^{11}$ Álvarez Caballero (1988), 53.

${ }^{12}$ Ibid. 54.

${ }^{13}$ Grande notes that the fact that the Gypsy community largely settled in Andalusian lands cannot be a coincidence, which would indicate certain cultural similarities between both groups of people. Felix Grande. Memoria del Flamenco. (Madrid: Espasa Calpe, 1987), 47. ${ }_{14}$ Peter Manuel, Popular Music of the Non-Western World (New York: Oxford University Press, 1988), 121.

${ }^{15}$ Cante is a derivation of the Spanish word canto (to sing, chant) and it's generally applied to the flamenco way of singing.
} 
EXAMPLE 1: Bulería rhythm pattern.

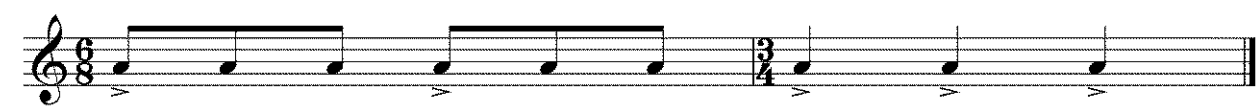

In the case of the solea, one of the most ancient and diversified flamenco chants, ${ }^{16}$ despite the fact that it is divided into twelve beats, it has a complex structure in some ways similar to the buleria, but it is based on a 3/4 time signature and the accents are positioned in different places:

EXAMPLE 2: Soleá thythm pattern.

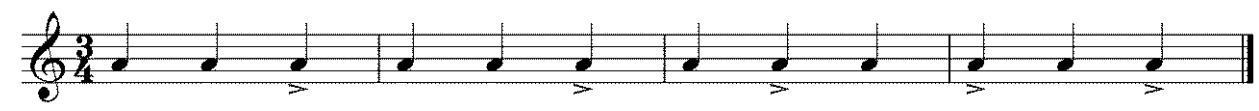

Another important characteristic element is the harmony, in which the concepts of Andalusian cadence and dominant flamenco scale stand out. The Andalusian cadence is a chord progression, generally descending, present in southern Spanish music at least since the Renaissance, and whose main characteristic is settling on a dominant chord:

EXAMPLE 3: Andalusian Cadence

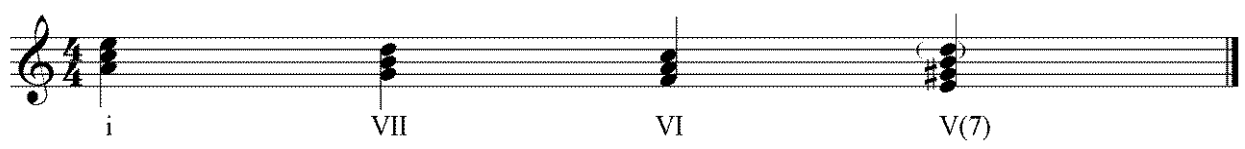

The personal and specific sonority of this progression ${ }^{17}$ has led different composers and performers to use it in order to give a Spanish or Andalusian tinge to their works. But even though it is a central harmonic structure in the flamenco art, it is not an exclusive feature.

Unlike the Andalusian cadence, the melodic approach over the dominant, the last chord of the progression, is exclusively flamenco. Over that harmony, flamenco performers tend to use the fifth mode from the minor harmonic scale when they want to keep the tension, and the third mode of the diatonic scale, Phrygian, when they want to create a complete or partial resolution. Therefore, the two thirds, major and minor, are alternated in a specific way that we could call flamenco resolution:

\footnotetext{
${ }^{16}$ As Peter Manuel reminds us, "it is sometimes referred to as the 'mother of cantes' and it does appear to have been a primary evolutionary source for certain cantes (especially alegrías and bulerías)." Peter Manuel, "Flamenco in Focus: An Analysis of a Performance of Soleares," in Analytical Studies in World Music, ed. M. Tenzer (New York: Oxford University Press, 2006),100.

${ }^{17}$ According to Manuel, in this cadence, the $\mathrm{E}$ chord functions more as a tonic than a dominant. Manuel (2006), 97.
} 
EXAMPLE 4: Buleria recorded by La Niña de los Peines in 1928 ( Que te queria no lo niego, Regal, RS 610) where we can observe the double third utilization.

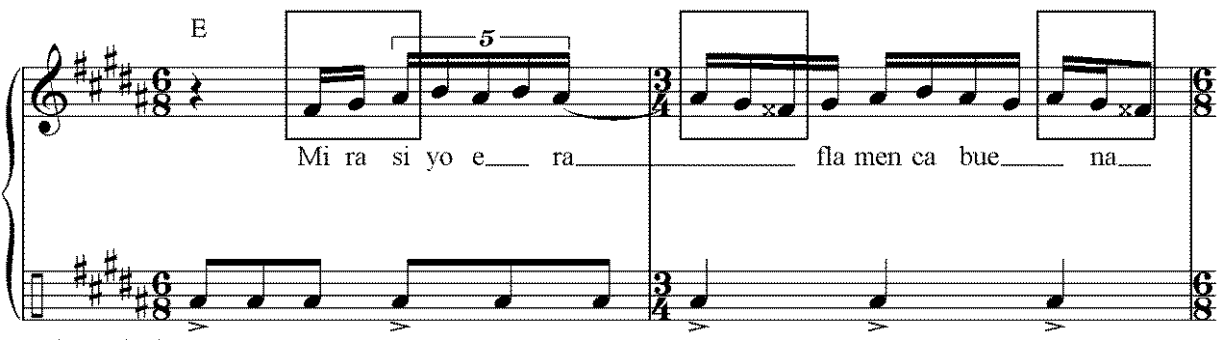

Buleria Rhythm Pattern

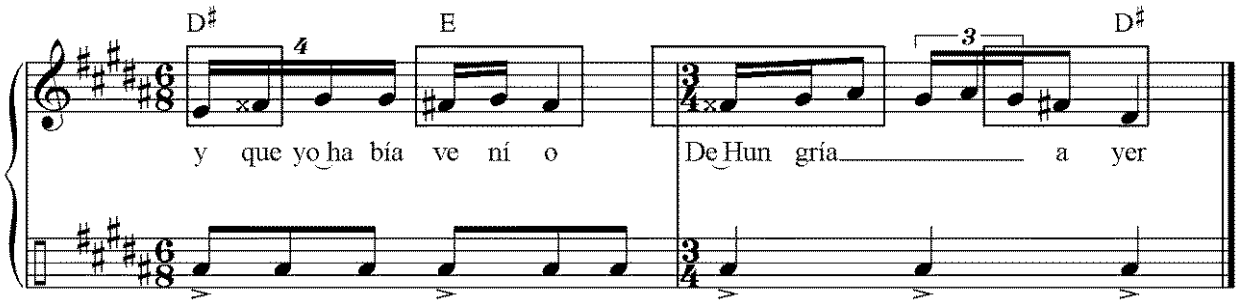

Flamenco is, therefore, a musical art whose roots are complex and deep. Additionally, flamenco has generally been approached superficially and has been confused with other musical representations from Spanish and Andalusian (and even Mexican and South American) folklore and from its reflections in the works of such Spanish classical composers as de Falla, Granados, and Albéniz. Despite its institutionalization around the nineteenth century, in part a consequence of the Romantic affinity for exotic sonorities and atmospheres, the temperament of flamenco performers has been extremely reserved and exclusive, defending the authenticity of pure flamenco, essentially that from the Café Cantante epoch. This systematic rejection of external influences, and a disapproval of the mass commercialization of singing and dancing, managed to preserve the spirit of flamenco until the second half of the twentieth century when artists like guitarist Paco de Lucía and singers Enrique Morente and Camarón de La Isla took a decisive stance that would lead to the sharing of flamenco with other cultures.

\section{JAZZ-FLAMENCO, FIRST STEPS TOWARDS A SOUND IDENTITY}

Over the course of history, jazz and flamenco have been repeatedly intertwined. This constant and recurrent relationship has led many musicians, scholars, and aficionados to reflect on the possible contact points between these different musical genres. Despite the fact that the encounters between flamenco and other artistic expressions have not been studied in depth, ${ }^{18}$ some scholars have advanced theories on the subject, including

${ }^{18}$ Pedro Calvo and José Manuel Gamboa, Historia-guia del nuevo flamenco. El duende de ahora (Madrid: La Encrucijada, 1994) 137. 
Germán Herrero, who compared both musical genres and pointed out that the universality of jazz opposes the introversion of flamenco. ${ }^{19}$ Clemente reinforces this idea, stating that in the 1950s, while jazz was being universalized, flamenco was passing through an introspective process. Therefore, while jazz continued down the expansionist path started by bebop, flamenco and "flamencology" looked to the past through research and a return to origins in an outburst of stylistic and academic purism and conservatism. ${ }^{20}$ As Peter Manuel points out, one of the reasons for this resistance to change in the Spanish culture was the repressive dictatorship of General Francisco Franco, which had disastrous consequences for Spanish culture and the country's economy. ${ }^{21}$ The end of his dictatorship in 1975 would prove to be a decisive factor in the liberalization of flamenco at the end of that decade. In any case, even though there are examples that unite jazz and flamenco starting in the 1920s, from the recordings of Ramón Montoya to the contributions of Lionel Hampton (1956), Miles Davis (1959) and John Coltrane (1961), one would have to wait until the 1970s to see real contact between the two musical genres, performed by musicians representative of the two cultures. It was then that the conditions on both fronts were ideal for a meaningful collaboration.

Thus, the question is clear: what were the motives behind the convergence of flamenco and jazz at that precise moment and who were the leading actors? In the case of jazz, the rise of fusion may have brought it closer to other musical realms, including flamenco. The release of Spaces, by Larry Coryell with Chick Corea and John McLaughlin in 1974 served as a catalyst, $^{22}$ given the subsequent involvement of these musicians in the fusion of both genres. Corea in particular would play a dominant role, as today many flamenco musicians find inspiration in his music. ${ }^{23}$ Furthermore, the consolidation of World Music would also sustain that interest.

On the other hand, why did flamenco turn to jazz at that specific time? Essentially, jazz musicians started to become interested in flamenco when Paco de Lucía began to delve into it. In addition, in the 1970s artists began to look for new fusions with other types of music, including jazz, to which attention was drawn by the popularity of the guitarist from Algeciras. ${ }^{24} \mathrm{Of}$

\footnotetext{
${ }^{19}$ Germán Herrero, De Jerez a Nueva Orleans. Análisis comparativo del flamenco y del jazz (Granada: Editorial Don Quijote, 1991), 115.

${ }^{20}$ L. Clemente, "Jazz-Flamenco Azulado," In In’n Out. In-Fusions de Jazz, ed. Julián

Ruesga Bono (Sevilla: Artefacto, 2010), 96.

${ }^{21}$ Manuel (2006), 94.

${ }^{22}$ Calvo and Gamboa (1994), 159-160.

${ }^{23}$ Ibid, 162.

${ }^{24}$ J. Blas Vega and Manuel Ríos Ruiz, "Devenir y auge del experimentalismo flamenco." La caña: revista de flamencolasociación cultural La Caña. No. 10, Oct. 1994 (Madrid: A.C. "España abierta", 1994), 9.
} 
course, as previously mentioned, de Lucía was able to take advantage of the new environment brought about by the death of the dictator and the start of democracy, which "opened the way for a torrent of previously repressed cultural expressions and socio-political movements-including Andalusian autonomy and gypsy mobilizations - which found expressions in popular music forms." ${ }^{25}$ Even so, Paco de Lucía acted both as a lure to the jazz world and as a guide for an entire generation of flamenco musicians, thanks to his open-mindedness, his tireless efforts, and his great artistic sensitivity and intelligence.

\section{PACO DE LUCÍA AND JAZZ}

Siempre seré un guitarrista flamenco, soy un guitarrista flamenco, pero de pronto tengo inquietud por conocer otras músicas y por saber cómo se toca en otras culturas y en otros estilos ${ }^{26}$.

A single ingredient was missing in this open context of the 1970s for the flamenco element to break with its traditional limitations: the capacity for experimentation, liberalization, and artistic risk-taking. Paco de Lucía, a guitarist trained in the flamenco tradition, undertook this role with a much broader vision than the rest of the flamenco musicians of his era. De Lucía had his first direct contact with jazz in 1967 on the album Jazz Flamenco by Spanish saxophonist Pedro Iturralde. It was part of a series of three records, two for the Spanish label Hispavox, Jazz Flamenco Vol. I (HH (S) 11-128) and Jazz Flamenco Vol. II (HH (S) 11-151), and one for the German label Saba, Flamenco Jazz: Pedro Iturralde Quintet-Paco de Lucia (SB 15-143 ST), recorded after the appearance of Iturralde and his band at the Berlin Jazz Festival in 1967. The latter was produced by Joachim E. Berendt and released in Germany in 1968.

These three albums, recorded by the same band with slight variations, revealed a new element that brought jazz and flamenco closer together: the inclusion of a flamenco guitarist within a jazz context. Hence, we find a jazz combo in which a flamenco guitarist participates, sometimes alternating, sometimes in an integrated manner, performing toque puro. ${ }^{27}$ On the Hispavox albums, Paco de Antequera is the guitarist on two of the

\footnotetext{
${ }^{25}$ Manuel (1988), 123.

26 "I'll always be a flamenco guitarist, I am a flamenco guitarist, but suddenly I get anxious to learn about other types of music and to see how it's played in other cultures and other styles" In Michael Meert. Paco de Lucia: Light and Shade (Euroarts, WDR, Arte, Televisión Española, 1994).

${ }^{27}$ Toque puro is the more conservative and accepted way of playing flamenco.
} 
tunes, while Paco de Algeciras plays on the rest. ${ }^{28}$ In truth, "Paco de Algeciras" was a pseudonym for the young Paco de Lucía, who could not appear under his own name on the album for contractual reasons. ${ }^{29}$ The overall aesthetic impression is very reminiscent of Coltrane's Olé, with the tunes based on popular Andalusian pieces similar to flamenco (among which is El Vito, the main melody in Coltrane's tune Olé), as well as new references to de Falla's works and different palos such as "Bulerías" and "Soleares." It is on this last piece, performed by sax and flamenco guitar alone, that we observe a direct contact between jazz and flamenco: a guitar player performing toque puro and a saxophonist emulating the cantaor, drawing melodic contours with clear jazz articulation. Even though the contact between both musical genres was evident in these recordings, each has clearly defined outlines. Nevertheless, this was de Lucía's first serious contact with jazz, and even though after the sessions he stated that he "hadn't understood a thing," ${ }^{30}$ it may have well have had an influence on his later understanding.

In 1976, a year after the death of General Franco, de Lucía collaborated on the album Elegant Gypsy by Al DiMeola and John McLaughlin, which put him on the international map and opened many doors. ${ }^{31}$ This momentum allowed him to form the "Tres Hermanos" along with McLaughlin and Coryell, which embarked on a lengthy tour through North America and Europe in 1979. Shortly thereafter, Al Dimeola replaced Coryell on the popular Friday Night in San Francisco-Live in 1981 and Passion, Grace $E$ Fire in 1983. According to flamencologist and personal friend of de Lucía, Felix Grande, the guitarist's introduction to these jazzmen was crucial not only for leading him to an admirable kind of music, but also to the notion that part of the harmonies could come from the flamenco guitar which, "if it lacked anything at that time, it lacked harmonic collaboration." 32 Beyond their significance as a fusion of jazz and flamenco, the tours allowed de Lucía to complete his training, ${ }^{33}$ especially

\footnotetext{
${ }^{28}$ In the Paco de Lucía discography included in his work Guitarra Flamenca. Vol II. (Sevilla: Signatura, 2009, 81), Norberto Torres states that de Antequera played only on "Las Morillas de Jaén," while de Lucía is the guitarist on the other songs.

${ }^{29}$ José María García Martínez, Del Fox Trot al Jazz Flamenco: el jazz en España: 19191996 (Madrid: Alianza Editorial, 1996), 199.

${ }^{30}$ A. Antonio Casas, Paco de Lucía. Vibraciones. November 1974, quoted in García Martínez (1996), 199.

${ }^{31}$ Calvo and Gamboa (1994), 159.

32 According to Grande, "flamenco guitar players, due to general conservative proximity, needed to be harmonically enriched via contact with other musicians and styles." Jesús de Diego and Daniel Hernández, Francisco Sánchez-Paco de Lucía (ALEA TV, Arte, Televisión Española, 2002).

${ }^{33}$ D.E. Pohren, Paco de Lucía y Familia: el plan maestro (Madrid: Sociedad de Estudios Españoles, 1992), 103.
} 
as an improviser, since improvising in flamenco isn't the same as improvising in jazz. ${ }^{34}$ De Lucía explained in an interview just what those tours meant for his growth as a musician:

Yo les preguntaba a ellos [Al DiMeola y John McLaughlin] ¿cómo improvisáis? ¿Cómo es el sistema? ¿Cuál es la forma? Y se reían. ¿Pero por qué te ríes hombre? ¡Venga hombre! ¿Te vas a quedar conmigo? ¡Si tú sabes! ¡Si yo no sé! Y no sabía. Hasta que ya empecé a descubrir cómo era aquello. Y el día que me di cuenta de cómo había que improvisar, pues ese día ya respiré. Respiré y, al poco tiempo de eso, empecé a descubrir lo bonito que era, la improvisación. [...] A la hora de improvisar, tienes que saber siempre qué armonía, dónde estás, musicalmente dónde estás, armónicamente. Y el sentido del riesgo, el no saber qué vas a hacer dentro de 15 segundos, tirarte a no sé... es difícil de explicar, es una abstracción. Pero la sensación es una maravilla. Y yo ya ahora no puedo prescindir de la improvisación. ${ }^{35}$

With the international exposure he garnered beginning in the second half of the 1970s, de Lucía may have been flamenco's greatest attraction for the jazz world. His jazz credentials were reinforced by the various recordings and tours of the period, which matched the guitarist from Algeciras with some of the great jazz figures of that era. In addition, de Lucia's uncommon sensitivity to other artistic realities and his courage in tackling them in depth with his own personal touch were instrumental in the revival of flamenco itself. He was assisted in that effort by his jazz counterpart: pianist Chick Corea.

\section{CHICK AND PACO, PACO AND CHICK: AN ANALYTICAL APPROACH}

Chick Corea is the jazz musician who has delved the deepest into flamenco music and contributed the most to the genre to date. His Latin roots and his collaborations with Mongo Santamaría in $1962^{36}$ produced

\footnotetext{
${ }^{34}$ Manuel (1988), 122.

35 "I would ask them [Al DiMeola and John McLaughlin] How do you improvise? What's the system? What's the form? And they would laugh. But why are you laughing, man? Come on! Are you fooling around with me? You know [the answer]! I don't know it! And I didn't know. Until finally I started to figure out how it went. And the day I realized how to improvise, well, that day I could breathe more easily. I breathed and, a bit later, I began to discover how beautiful it was, improvisation [...] When you improvise, you always have to know what the harmony is, where you are, musically speaking, where you are harmonically. And the feeling of risk, of not knowing what you're going to do in 15 seconds, to go who knows where... it's difficult to explain, it's an abstraction. But it's a marvellous feeling. And now I can no longer do without improvisation.” In Meert. Paco de Lucia: Light and Shade (1994).

${ }^{36}$ Lewis Porter. Corea, Chick (Armando Anthony). Encyclopedia of Jazz Musicians at www.jazz.com [Last visit: 4-30-2012].
} 
compositions with a marked Latin character. Beginning in 1972, when Corea included the tune "Spain" in his album Light as a Feather (Polydor, 827 148-2), references to Latin and Spanish music became a hallmark of his multifaceted style. Corea's personal interest in Spanish music was not limited to reproducing clichés but in discovering the essence of the music. Pedro Ample, founder of the Spanish band Dolores, from which de Lucía later took an important part of his Sextet in Jorge Pardo and Rubem Dantas, remembered:

Entre 1971 y 1974 nuestras aventuras nocturnas partían del tablao Café de Chinitas [...] Una noche me encuentro allí sentados a la mesa a Chick Corea, Stanley Clarke y Lenny White, que tocaban dos días después en el Monumental Return to forever. Yo, que era un lanzaíllo, me acerqué... Tengo fotos en plan guiri bailando al final con ellos en el escenario. Le caí muy bien a Chick y me pidió que fuera a buscarle al día siguiente a buscarle para enseñarle Madrid y llevarle a comprar discos [...] le hablé de Paco de Lucía, y se compró dos, tres discos de él. ${ }^{37}$

Therefore, it seems that Corea knew Paco's work before embarking on his first full Spanish-themed project, My Spanish Heart (Polydor, 2669 034), though the album shows little relationship to real flamenco or de Lucía's music. The tremendous complexity of the concept, with its many different textures, provides an overview of Corea's creativity--from the Latin rhythms of "Night Streets," the long piano solos topped with a vocal layer in "My Spanish Heart," to the excellent role of the string section in "The Garden" and "Day Dance." The album ends with two short suites, El Bozo and Spanish Fantasy. In the first, which consists of a prelude and three sections, synthesizers are in the forefront and references to Spanish or Latin approaches are considerably reduced.

However, the second suite, Spanish Fantasy, more directly alludes to Spanish sounds, with frequent references to the Andalusian cadence by the acoustic piano. The third section, for solo piano, is especially notable, as Corea explores different sonorities while maintaining contact with the Spanish aesthetic at all times. The fourth and last part of the suite stretches the limits of progressive rock, undoubtedly influencing bands from the obscure Rock Andaluz (Andalusian Rock) movement in which Andalusian and flamenco influences were mixed with those of bands such as Yes, Pink

\footnotetext{
37 "Between 1971 and 1974 our nocturnal adventures began at the tablao Café de Chinitas [...] One night I find sitting there at the table Chick Corea, Stanley Clarke and Lenny White, who played Return to Forever two days later at the Monumental. Me, I was very forward at that time, I went there... I have pictures of myself acting like a tourist, dancing with them on stage. Chick liked me and asked me to pick him up the next day in order to show him around Madrid and take him to shop for records [...] I told him about Paco de Lucía, and he bought two or three of his records." José Manuel Gamboa, Una Historia del Flamenco (Madrid: Espasa, 2005), 89.
} 
Floyd and King Crimson. This genre's greatest exponents were Triana, Alameda, Smash, Tabletom, and Imán.

The album's complexity and wide range of shades are impressive, but, in light of the fact that Corea was aware of Paco de Lucía's work, the question remains: what real flamenco elements exist on this record? The answer, provided by historical perspective and musical analysis, is clear. Corea does not use falsetas in his phrasing, nor is there a clear flamenco rhythmic element. What Corea does show is a clear tendency towards experimentation and stylistic openness, integrating basic elements of jazz with modern synthesizers, string sections and vocal ensembles, and Latin sounds transcending those of the distant Spain of de Falla and Rodrigo, all while creating music that always sounds like his own.

As for Paco de Lucía, he occupies a central position in the history of flamenco, not only as a reference point and the father of modern flamenco guitar, but also as a major precursor to the mainstreaming of this musical art. This openness led him to experiment and fuse flamenco with other genres like Latin music, classical music, and jazz. Despite the traditional rejection by most flamenco purists of anything that could "contaminate" their art form, de Lucia was drawn to other musical realities, among them the works of Chick Corea:

A Paco de Lucía me lo encontré una mañana en la cafetería de Fonogram [...] le dije que Chick Corea estaba alucinando con sus discos. "Ah, sí, jyo he oído un disco suyo que se llama My Spanish Heart que es una maravilla!" 38

This mutual cross-interest bore fruit in 1982 with the release of Chick Corea's album Touchstone, which featured Paco de Lucía as a guest. But before that, Paco had taken a major step by introducing another essential instrument into the current conception of flamenco, as he previously had with the cajón. ${ }^{39}$ It was during the recording of the album Paco de Lucia Interpreta a Manuel de Falla that de Lucía offered his personal vision of the celebrated musician from Cádiz by introducing in certain sections a new element: the flute. Pedro Ample recalled:

Lo vi claro desde el principio y empecé a insistirle a Paco sobre Jorge Pardo Cordero [Madrid, 1 - XII - 1956]: "¿'Tú has oído en el disco de Dolores a un chaval que toca la flauta?" "Sí, pero es que en el flamenco la flauta... Me van a matar, no lo van a entender.” Le seguí insistiendo. Yo creo que Paco, como es más listo que el hambre, quería; por eso me

\footnotetext{
38 "I met Paco de Lucía one morning in the café bar Fonogram [... I told him Chick Corea was psyched about his albums. 'Ah, yes, I heard one of his records called My Spanish Heart and it's amazing!" Gamboa (2005), 89.

${ }^{39}$ The "cajón," a Peruvian instrument which is currently used regularly in flamenco, was introduced by Paco de Lucía through his percussionist Rubem Dantas.
} 
dejó que yo le comiera la cabeza a Ramón de Algeciras, al de la compañía de discos y a todos. Tengo la intuición de que él ya había tomado la determinación de meter la flauta. ${ }^{40}$

This innovation was significant on several levels, but especially in the introduction of clear jazz elements in a mainly flamenco context. In the second half of the 1970s, Jorge Pardo, despite his youth, had settled into the Madrid music scene, thanks to, among other things, his work with the band Dolores. For Pardo, jazz was an important part of his improvisational vocabulary. The flutist was invited, along with other Dolores members, to collaborate on Paco de Lucía's album interpreting Manuel de Falla, in what would be his first recording with a great flamenco musician. Soon thereafter he would do the same with Camarón, on the historic álbum $L a$ Leyenda del Tiempo (1979), and later on with great jazz artists like Corea. In fact, Pardo is currently considered one of the most accomplished flamenco fusion musicians ${ }^{41}$ and is accepted by many sectors of the flamenco world thanks to his versatility. ${ }^{42}$

Pardo played a crucial role in the tribute album to Manuel de Falla, one of the projects on which De Lucía dealt with music in the classical tradition. In the song "La Canción del Fuego Fatuo," which was also recorded by Miles Davis and Pedro Iturralde, de Lucía stays true to the original score during the main theme exposition, but later abandons it, changing the rhythmic approach and introducing percussion, bass and flute. In the final section, Pardo is given space for short solos, into which he introduces unmistakably jazz phrases:

EXAMPLE 7: Pardo's early mix between jazz and flamenco language

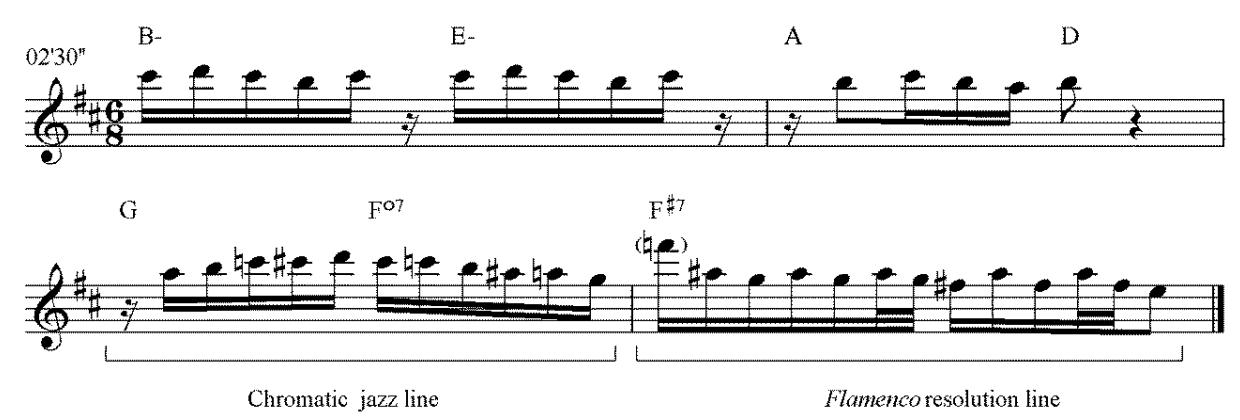

40 "I saw it clearly from the beginning and I started to push Paco about Jorge Pardo Cordero: 'Have you heard a guy who plays the flute on the Dolores record?' 'Yes; but the flute in flamenco... They are going to kill me; they are not going to understand it.' I kept pushing him. I believe that Paco, because he is so smart, he was willing to try it out. Because of that, he let me try to convince Ramón de Algeciras, the guy in the record company, and everybody else. I have the feeling that he had already decided to add the flute," Gamboa (2005), 89.

${ }^{41}$ Calvo and Gamboa (1994), 181.

${ }^{42}$ Blas Vega and Ríos Ruiz (1994), 11 
In addition, Pardo stresses the use of descending phrases similar to the flamenco style, with special emphasis on the double third (3 and b 3), which plays a more structural role in what could be a mixture of natural Phrygian and Phrygian major, but also corresponds to the half-whole tone scale over F\# dominant:

EXAMPLE 8: Pardo approaches flamenco and jazz with certain non diatonic notes

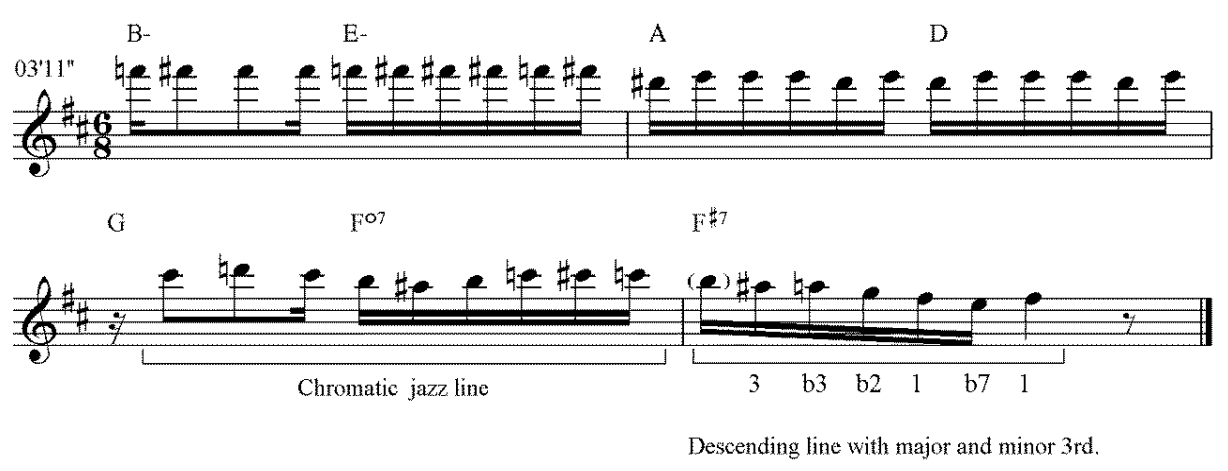

EXAMPLE 9: Different options for Pardo's resolution

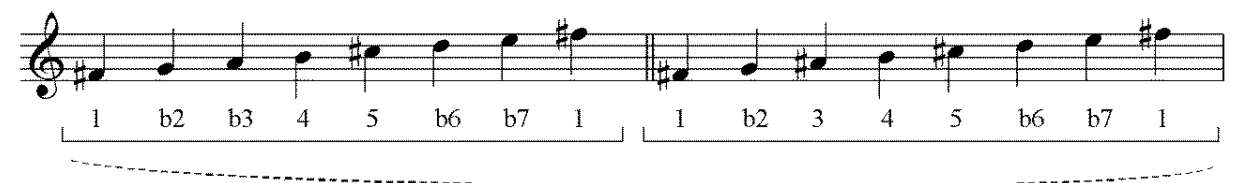

Phrygian \& Phrygian Dominant

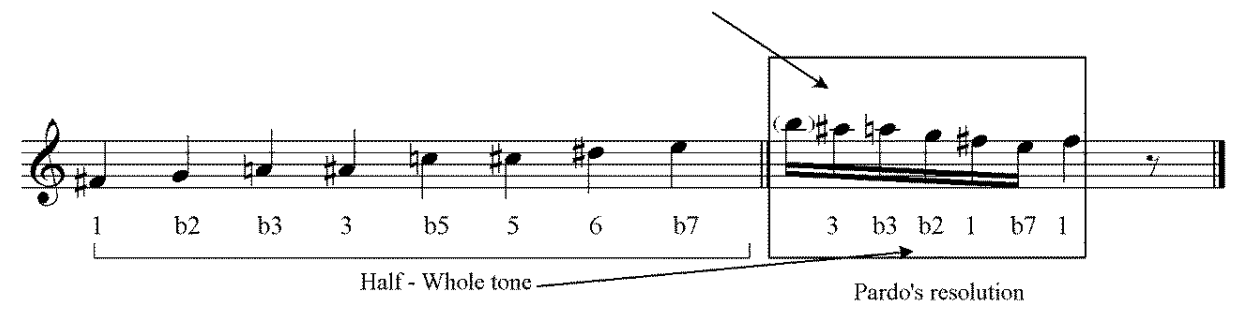

Unlike the albums by Iturralde, we find phrases and certain ways of playing coming from the jazz tradition in a context that, although oriented towards modernity, is undoubtedly flamenco-related. The work of Paco de Lucía in the mainstreaming of flamenco music was not limited to the incorporation of the flute or the cajón, but allowed an inclusive approach to the entire culture of jazz. De Lucia continued to explore this approach on subsequent recordings.

Such was the case on Solo Quiero Caminar (1981), again featuring Jorge Pardo and the Catalonian bassist Carles Benavent, thus forming the Paco de Lucía Sextet. The musical direction that de Lucía had been introducing into flamenco for years and which surfaced on the de Falla tribute album 
was solidified on this recording. ${ }^{43}$ Specifically, the compañía, a term used to define a flamenco band, assumes a jazz combo distribution, giving the solo guitarist the freedom to fulfil a more melodic and improvisational role. ${ }^{44} \mathrm{De}$ Lucía refers to this explicitly:

Ya dentro de la música flamenca, creo que fui el primero que empezó a organizar la improvisación, para que todo el grupo pudiera tocar... Dejo abiertas unas parcelas en las que recurro a unos tipos de acordes en donde pueden sentirse libres y expresarse ellos mismos, no como ocurre con la mayoría de los divos de la música en España, que obligan a los músicos a tocar nota a nota lo que tú les dices que toques. ${ }^{45}$

This wasn't the only element that de Lucía borrowed from jazz for this release. The band was presented as the Paco de Lucía Sextet, a name coming from the jazz culture, ${ }^{46}$ and comprising de Lucía on guitar, his brothers Pepe de Lucía and Ramón de Algeciras on vocals and guitar, Benavent on bass, Pardo on flute and saxophone, and Rubem Dantas on percussion. As noted by Norberto Torres, one of the most prominent de Lucia specialists, the similarities between this group and one of Corea's most famous bands, Return to Forever from 1972, are more than coincidental: Corea on keyboard, Flora Purim on vocals, Airto Moreira on percussion, Joe Farrell on flute and saxophone, and Stanley Clarke on bass. ${ }^{47}$

The aesthetic result of this album, especially on compositions such as "Palenque" and "Convite," 48 is innovative and risky, and considerably expanded the borders of flamenco music. The bass plays a central role, with a sound close to that of Jaco Pastorius and phrasing loaded with allusions to Paco's falsetas. ${ }^{49}$ The guitar develops a melodic solo in which pure flamenco sections are alternated with other less orthodox passages more similar to the jazz approach:

\footnotetext{
${ }^{43}$ Juan José Téllez, Paco de Lucía en Vivo (Madrid: Plaza Abierta, 2003), 347.

${ }^{44}$ Norberto Torres, "Paco de Lucía o el Miles Davis del Flamenco," La caña: revista de flamencolasociación cultural La Caña. No 10, Oct. 1994 (Madrid: A.C. "España abierta," 1994), 40-41.

45 "Within flamenco music, I believe I was the first to begin to organize improvisation, so that the whole group could play... I leave spaces open in which I turn to types of chords where they can feel free to express themselves, unlike most of the stars in Spanish music, who force their musicians to play what they tell them, note for note." Téllez (2003), 10-11.

${ }^{46}$ Torres (1994), 41.

${ }^{47}$ Ibid., 41.

${ }^{48}$ As noted by Téllez, the influence of Brazilian music on Paco de Lucía's ideas is clearly observed on this track, which shows his openness to different sources of inspiration.

Téllez, (2003), 21.

${ }^{49}$ Falsetas are short melodies with an implicit rhythm that make up the improvisational vocabulary of flamenco players, similar to the concept of a lick.
} 
EXAMPLE 10: De Lucia's final phrasing, also mixing jazz and flamenco elements in the song Convite
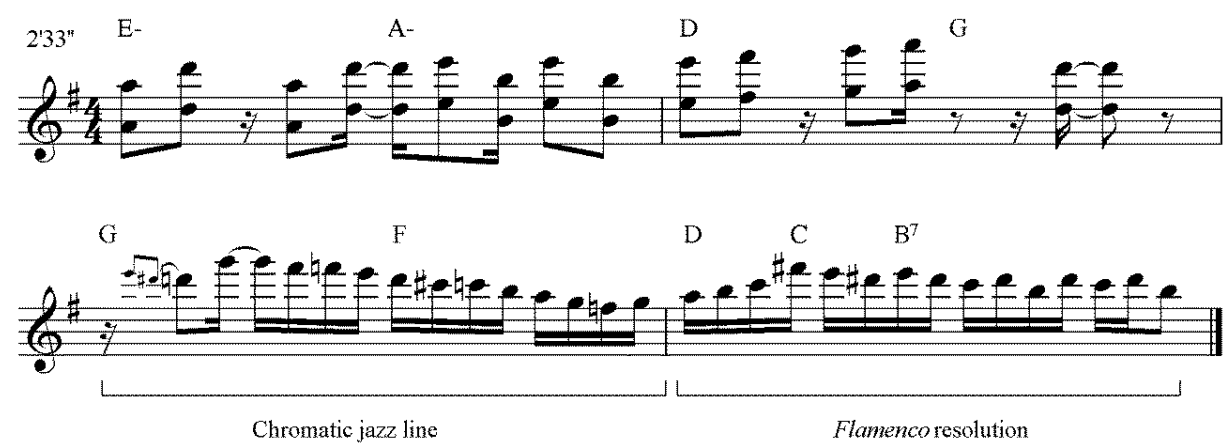

Jorge Pardo assumes a leading role and has multiple opportunities for soloing. The introduction in flamenco of a new instrument, the saxophone, in the tune "Palenque" is also notable. On this instrument, Pardo achieves a distinctly flamenco sound, with the intensity and roughness of the flamenco cantaores, without sacrificing the jazz articulation and phrasing-a point of convergence. Pardo pushes the combination of flamenco and jazz elements even further. In his flute solo on "Convite," he uses a curious application of the whole tone scale, an option that does not fit with B dominant:

EXAMPLE 11: Jorge Pardo using the whole tone scale over the andalusian cadence, also in Convite
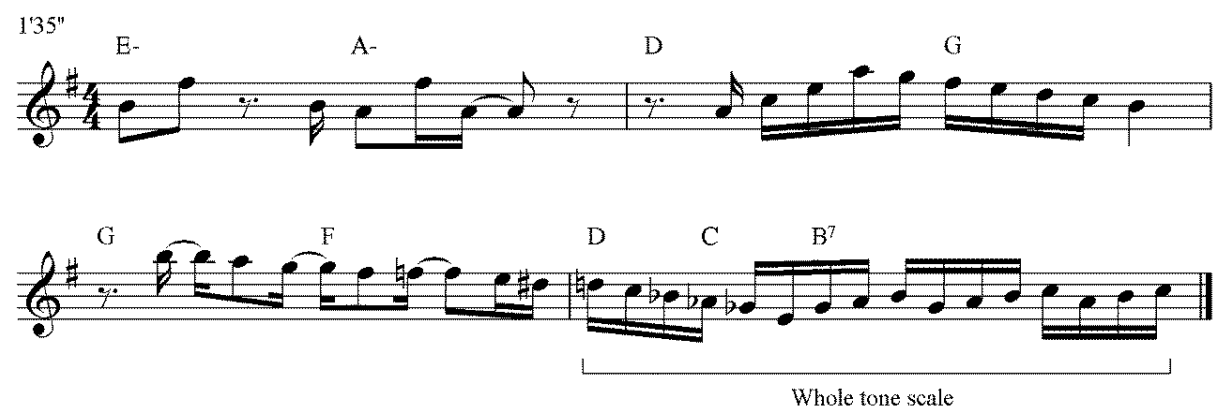

There is a very high degree of complexity and elaboration of the prevailing concept on the record, and traces of Corea's albums from the 1970s are noticeable. Moreover, the personality of de Lucía's guitar in conjunction with the deep sound of Benavent, the unmistakable phrasing of Pardo, and the distinctive percussion of Dantas, established the foundation of a style and sound that would continue to develop throughout the 1980s and 1990s, and which is still evolving today.

The following year, with Paco's sextet in full swing, saw the release of Corea's album Touchstone (1982), which boasted a large cast of musicians, including de Lucía and Benavent. The absence of Pardo and the first 
flamenco cajonero, ${ }^{50}$ Rubem Dantas, was surprising, although the native cajoneador Alex Acuña is featured. Corea introduces an interesting concept, particularly evident on the first two tracks, "Touchstone" and "The Yellow Nimbus." Moreover, the rhythmic concept on "The Dance of Chance," which closes the album, is notable for its singular interpretation of the bulerias pattern.

This represents a real meeting of jazz and flamenco at the highest level. The inclusion of de Lucía's guitar in Corea's complex stylistic conception, together with Benavent's bass approach that is beginning to sound flamenco, seems to have provided these pieces with a truly new identity. The solos are brilliantly performed, with each of the musicians offering his own style and interpretation. The different solutions offered by each player to the tensions produced by the various harmonic situations are outstanding. The first track, "Touchstone," contains a central section during which Corea, de Lucía and Benavent play solos that reveal both the individual perception of each musician and a common approach to the resolutions. Corea uses up to three different applications over a flamenco dominant, $\mathrm{C} 7$, in two bars:

EXAMPLE 12: Chick Corea applies three different devices over C dominant.
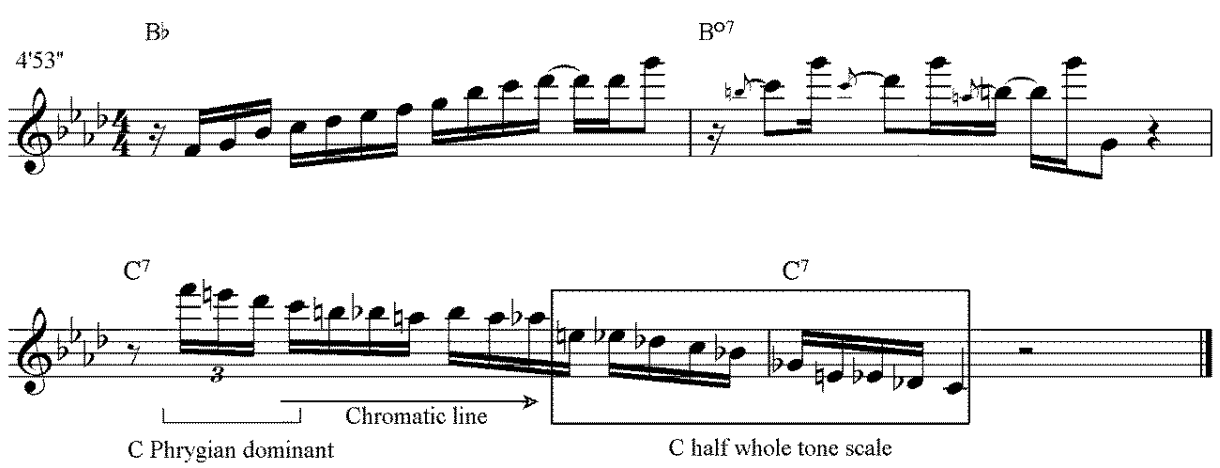

The phrase begins with a descending line in which the structural tones of the Phrygian major scale are played, connecting them with an explicit application of the half-whole tone scale over $\mathrm{C}$ through a clear, descending chromatic line. The use of the half-whole tone scale by musicians outside of the flamenco culture may be due to the inclusion of the two thirds, major and minor, generally coming from an alternate implementation of Phrygian and Phrygian major, in addition to its exotic sound which is often employed by jazz improvisers. This formula seems to be repeated a little later, although not as clearly. Again, Corea creates a phrase by using material from the $\mathrm{C}$ Phrygian major scale, although here he introduces the

${ }^{50}$ Gamboa (2005), 92. 
note D natural. Subsequently, he uses new chromatic material to finish the phrase with notes around the half-whole scale, though now less explicitly:

EXAMPLE 13: Corea's complex phrase with different interpretations
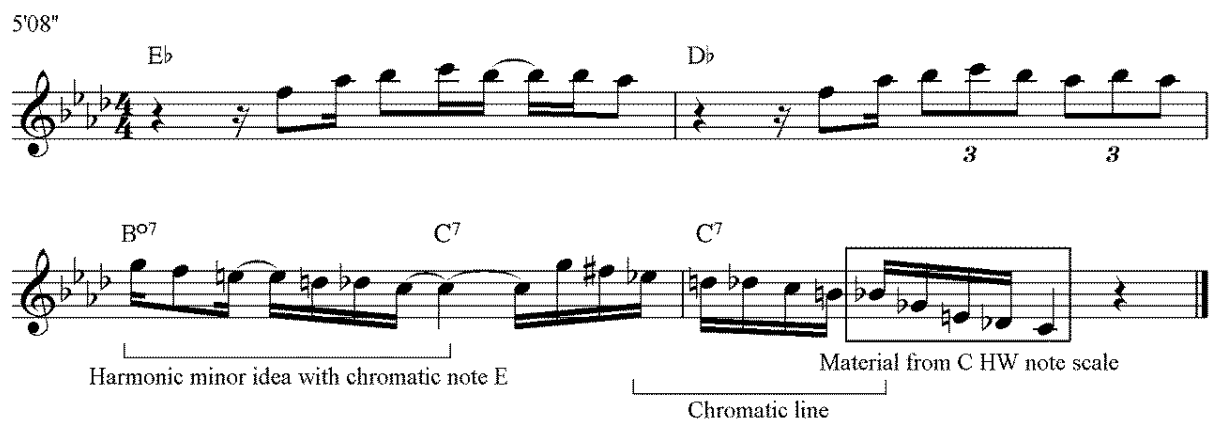

Over the same chord progressions, de Lucía and Benavent use different approaches. The guitarist offers a clear example of the use of the double third for flamenco resolution, and also takes risks with structures which are not necessarily diatonic:

EXAMPLE 14: Paco de Lucia uses the descending flamenco double third

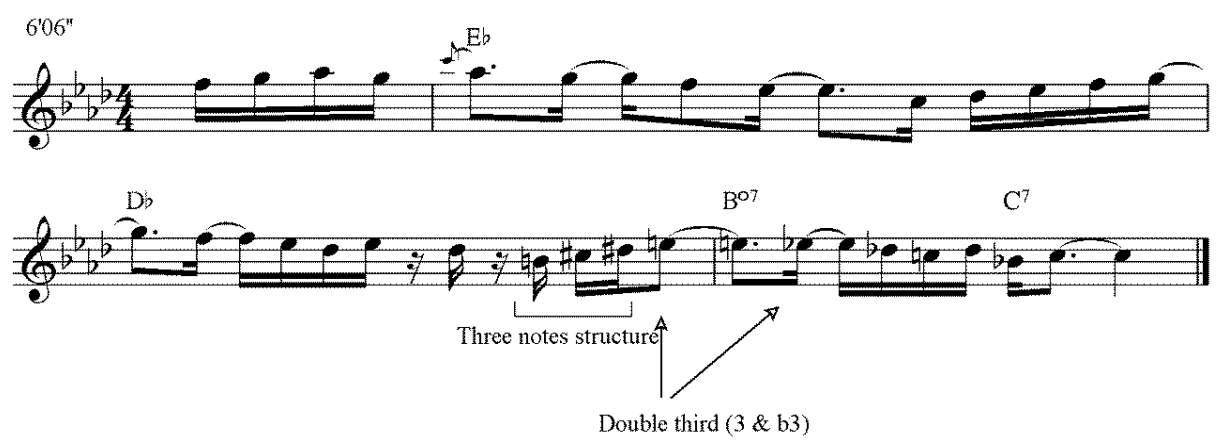

The three notes prior to the time resolution we just observed could come from the whole note scale, common in de Lucía's vocabulary at that time, although the length of the idea does not define his true purpose. Benavent's intentions were much clearer, as his vocabulary shows how he was assimilating de Lucía's falsetas and his tendency to use pentatonic structures. Thus, in the song "Touchstone," Benavent clearly overlaps pentatonic structures with some liaison notes over the $\mathrm{Bb}$ diminished chord during the first two beats of the bar prior to resolution in order to focus on the C Phrygian major in a very "flamenco" way: 
EXAMPLE 15: Benavent applies Db major pentatonic over $\mathrm{B}^{\circ} 7$ and resolves with $\mathrm{C}$ Phygian dominant
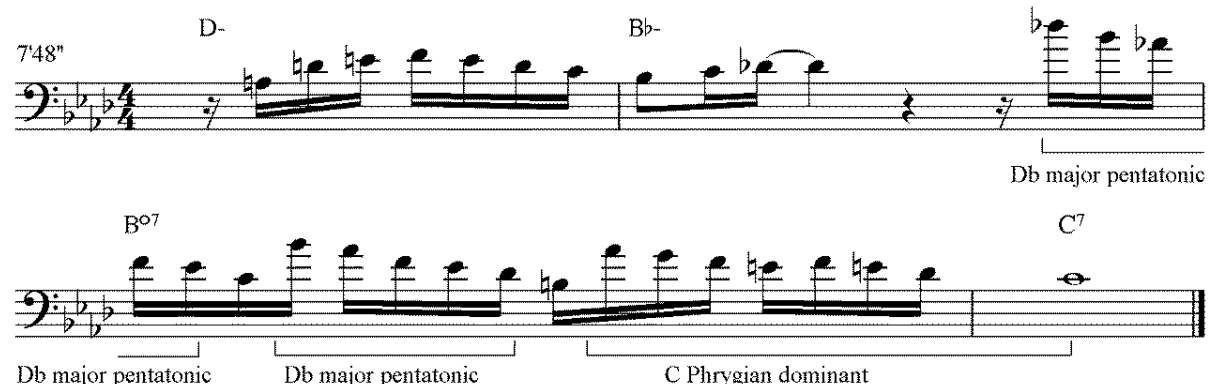

It's clear through these recordings that Corea has a broad vocabulary, with a tremendous ability to combine different resources during the resolutions without losing the fluidity of the line or the musicality. There is also a clear influence of flamenco in the resolutions, both in the composition of the chord progression and in the approaches applied over those progressions, although the use of the half-whole tone scale goes beyond the boundaries of traditional flamenco. Paco de Lucía, meanwhile, demonstrates outstanding improvisational ability on this recording, given the historic moment and in spite of the distinctive characteristics of the conservative flamenco environment. The use of chromaticism and other improvisational resources, possibly adopted from his experience playing with John McLaughlin and Al Di Meola, represent a huge advance in the mainstreaming of flamenco, although we can observe the roots and the authenticity of his own tradition in the resolutions. For Benavent, the pentatonic approach brought his concept closer to his rock origins, but the continuous allusions to falsetas flamencas, his versatility, and his enormous musical personality contribute even more depth to Corea's concept.

\section{CONCLUSIONS}

The musical interaction of different cultures during the current era of globalization opens new perspectives on the interpretation of the past. The lengthy relationship between flamenco and jazz has not been observed in depth or analytically from different musicological viewpoints. The experiments conducted by Ramón Montoya and the guitarist Sabicas from the flamenco side, as well as the recordings made by Lionel Hampton, Miles Davis and John Coltrane, to name the most prominent, contributed to normalise the jazz-flamenco relationship. But to find great musicians from both genres involved in joint artistic initiatives with a clear mutual acculturation process, we have to wait until the 1970s. During those years, jazz opened new paths through fusion, which was added to the peak period of World Music, and the bursting of a virtuosic, open-minded flamenco guitarist upon the international scene. The fall of the Franco administration 
allowed Spanish culture to reawaken at the exact time that Paco de Lucía began to assimilate his jazz experiences. The guitarist was able to work with musicians from the other musical world, breaking down the barriers of stagnant flamenco purism and illuminating the path that many flamenco musicians would follow later on. Meanwhile, Chick Corea was making contributions within the jazz style of the 1970s, serving as a key figure in the development and consolidation of fusion. His clear affinity for Latin and Spanish music led to his meeting Paco de Lucía and embarking on a series of compositions and collaborations that would culminate in 1) a mutual acculturation process and 2) the emergence of a group of musicians who, through ties with both cultures, developed a series of musical and aesthetic skills that allowed them to function for the first time in both styles. The most distinguished example is that of the flutist and saxophonist Jorge Pardo, who continues to build his career by developing a mixed vocabulary incorporating jazz and flamenco.

The origins of de Lucía's interest in jazz music can be found in an interesting musical concept that occurred in Spain circa 1967. It was promoted, in part, by the German critic and historian Joachim E. Berendt and carried out by the Spanish saxophonist Pedro Iturralde, who introduced a flamenco guitarist to his jazz quintet. The participation of this new element did not happen in improvisational sessions. However, both the choice of tunes and the rhythmic solutions, in addition to the incorporation of pure flamenco playing, brought jazz and flamenco into contact, although still in a predominantly jazz context. The flamenco guitarist on most of the recorded tracks was a young Paco de Lucía, who then continued experimenting outside his own genre.

In the 1970s, Corea also showed interest in, and a particular vision of, Spanish and Latin music, which he demonstrated with the composition and recording of a tune that has become an essential standard: "Spain." In 1976, probably already familiar with Paco de Lucía's music, Corea released My Spanish Heart, in which flamenco is not directly present but in it we find sonorities from Spanish classical music and blurred boundaries between the Spanish and the Latin approaches. In turn, Paco de Lucía expanded the boundaries of flamenco with his 1978 release of a tribute album to the Andalusian composer Manuel de Falla. Approaching the project from a modern and bold perspective, de Lucia included the flutist and saxophonist Jorge Pardo, who began to introduce unambiguous jazz elements into an unmistakably flamenco context. In 1981, the album Solo Quiero Caminar, by Paco de Lucía, was released, once again with the participation of Pardo, Carles Benavent and Rubem Dantas. Dantas, a member of the famous Paco de Lucia Sextet, internationalized the "new flamenco.” In addition, Pardo's distinctive style, which included saxophone on the recordings with the torn tone of a cantaor, Benavent's deep bass 
sounds, alternating between rock, flamenco and jazz, and Dantas' rhythmic perception, which introduced a number of unusual percussion elements to flamenco, generated a sound and aesthetic that was consolidated over the years, and which has come to be perceived as the essence of jazz-flamenco. In later years, these musicians toured with both Corea and de Lucía, two of the major figures in each style.

De Lucía and Corea finally came together in 1982 with the release of Touchstone, which would become Corea's closest album to Spanish and flamenco music. Paco's guitar, more mature and versatile than in the recordings with Iturralde, fit perfectly with the concept undertaken by the pianist and added authenticity, while providing excellent solutions to the different melodic and harmonic situations. Corea's music is much closer to flamenco in this album, both compositionally and in execution. In the flamenco resolutions (which remain in the dominant), Corea tends to use the half-whole scale, while De Lucía intuitively seeks sounds around a Phrygian approach built over the dominant, playing the minor third of the mode off the major third of the chord-a common flamenco practice. Benavent's participation is also notable for his dynamic bass work, which projected his exuberant personality, and his solos, which incorporated falsetas from de Lucía's repertoire.

The legacy of these records has continued to grow over the years. Paco de Lucía continued to work with Pardo, Benavent and Dantas, consolidating that sound and that aesthetic, once again collaborating with Chick Corea on the album Zyryab (1990). Likewise, these three musicians recorded their own albums and collaborated with other artists, including touring with Corea-the greatest achievement possible for a Spanish musician in jazz. In addition, their participation in jazz and flamenco projects made them central figures in the genesis of what is now known as jazz flamenco, which continues to evolve in the hands of such musicians as Chano Domínguez and Gerardo Núñez.

\section{BIBLIOGRAPHY}

Álvarez Caballero, A. Gitanos, Payos y Flamencos, en los orígenes del flamenco. Madrid: Editorial Cinterco, 1988.

Berlanga, Miguel Ángel, Culturas trashumantes. Música de las culturas gitanas desde la India hasta Europa. Collaboration with the Santander International Festival. Historical frameworks. Marcelino Botín Foundation. Introduction and Notes to the Programme. DL: SA-5432008, 1988.

Blas Vega, J. and Manuel Ríos Ruiz. "Devenir y auge del experimentalismo flamenco," La caña: revista de flamencolasociación cultural La Caña. No. 10, Oct. 1994. Madrid: A.C. "España abierta," 1994. 
Calvo, Pedro and José Manuel Gamboa. Historia-guia del nuevo flamenco. El duende de ahora. Madrid: La Encrucijada, 1994.

Clemente, L. "Jazz-flamenco azulado," In In'n Out: Infu-sions del Jazz, edited by Julián Ruesga Bono. Sevilla: Artefacto, 2010.

Gamboa, José Manuel. Una Historia del Flamenco. Madrid: Espasa, 2005.

García Martínez, José María. Del Fox Trot al Jazz Flamenco: el jazz en España: 1919-1996. Madrid: Alianza Editorial, 1996.

Grande, Felix. Memoria del Flamenco. Madrid: Espasa Calpe, 1987.

Herrero, Germán. De Jerez a Nueva Orleans. Análisis comparativo del flamenco y del jazz. Granada: Editorial Don Quijote. 1991.

Lévi-Provençal, Évariste. La Civilización Árabe en España. Madrid: Espasa Calpe, 1955.

Manuel, Peter. Popular Music of the Non-Western World. New York: Oxford University Press, 1988.

Manuel, Peter. "Flamenco in Focus. An Analysis of a Performance of Soleares." In Analytical Studies in World Music, edited by Michael Tenzer, New York: Oxford University Press, 2006.

Molina, Ricardo and Antonio Mairena. Mundo y formas del cante flamenco. Sevilla: Al-Andalus. 1979.

Pohren, D.E., Paco de Lucia y Familia: el plan maestro. Madrid: Sociedad de Estudios Españoles, 1992.

Porter, Lewis. Corea, Chick (Armando Anthony). Encyclopedia of Jazz Musicians at www.jazz.com [Last visit: 4-30-2012].

Ríos Ruiz, Manuel. Introducción al Cante Flamenco. Madrid: Ediciones Itsmo, 1972.

Ríos Ruiz, Manuel. El Gran Libro del Flamenco. Vol. I. Madrid: Calambur Editorial, 2002.

Téllez, Juan José. Paco de Lucía en vivo. Madrid: Plaza Abierta, 2003.

Torres, Norberto. "Paco de Lucía o el Miles Davis del Flamenco," La caña: revista de flamencolasociación cultural La Caña. No. 10, Oct. 1994. Madrid: A.C. "España abierta," 1994.

Torres, Norberto. Guitarra Flamenca. Vol II. Sevilla: Signatura, 2009.

Paco de Lucia: Light and Shade. Euroarts, WDR, ARTE, TVE

\section{DISCOGRAPHY}

Coltrane, John (1961): Olé. Atlantic LP 1373

Corea, Chick (1973): Light as a Feather. Polydor, 827 148-2

--- (1976): My Spanish Heart. Polydor, 2669034

--- (1982): Touchstone. Stretch Records, SCD 9003-2

--- (2005): Rhumba Flamenco. CCP 001 
--- (2006): The Ultimate Adventure. Stretch Records, SCD 9045-2

Davis, Miles (1959): Kind of blue. CL 1355

--- (1960): Sketches of Spain. CK 65142

De Lucia, P. (1978): Paco de Lucía interpreta a Manuel de Falla. Philips 836 032-2

--- (1981): Solo quiero caminar. Philips 810 009-2

--- (1990): Zyryab. Philips 846 707-2

García Lorca, Federico. \& Encarnación López Júlvez (1990): Colección de canciones populares españolas. Recogidas armonizadas e interpretadas por Federico García Lorca (piano), La Argentinita (voz). Sonifolk CDJ 105 (original: 1931)

Hampton, Lionel (1956): Jazz Flamenco. RCA 3L12015

Iturralde, Pedro (1967): Jazz Flamenco. Hispavox, HH (S) 11-128

--- (1968): Jazz Flamenco. Vol. 2. Hispavox, HHS 11-151

--- (1968): Flamenco Jazz: Pedro Iturralde Quintet - Paco de Lucía. Saba, SB $15143 \mathrm{ST}$

\section{ABOUT THE CONTRIBUTOR}

JUAN ZAGALAZ was born in Málaga, Spain, where he studied classical guitar in the Superior Conservatory. After finishing the program, he earned a Masters in Musicology in La Rioja University and studied at the Musicians Institute of Technology in Los Angeles, California. He finished his European doctoral studies in 2010, earning a $\mathrm{PhD}$ from the University of Jaén, Spain. He currently works in the University of Castilla-La Mancha. 